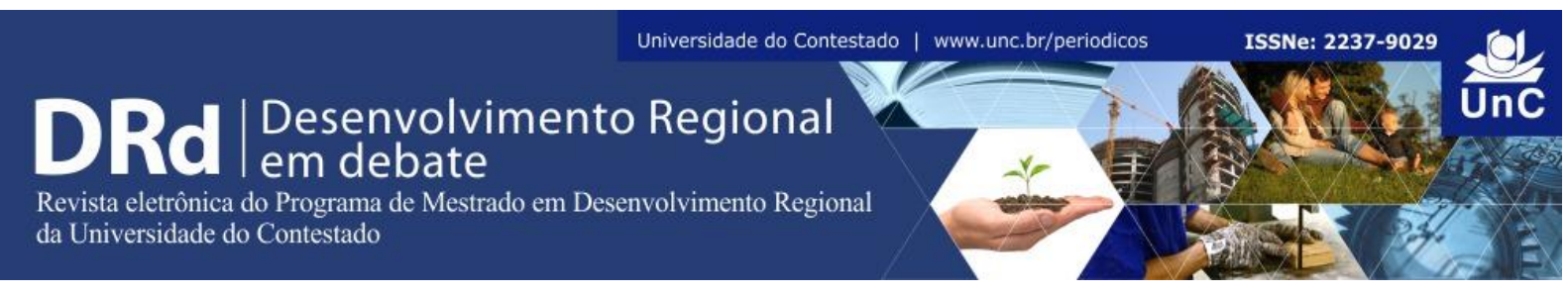

\title{
AS REPRESENTAÇÕES SOCIAIS E AS IMPLICAÇÕES DA POBREZA NO DESENVOLVIMENTO DO PLANALTO NORTE CATARINENSE
}

\author{
Maria Luiza Milani ${ }^{1}$ \\ Pollyana Weber da Maia Pawlowytsch ${ }^{2}$
}

\begin{abstract}
RESUMO
O objetivo do estudo foi o de analisar as representações sociais dos sujeitos que vivem em condição de pobreza no Planalto Norte de Santa Catarina, bem como os desafios que essa situação social representava ao desenvolvimento da região. Nesse território a pobreza vem sustentando indicadores sociais que instigaram estudos e reflexões, o que levou ao desenvolvimento desta pesquisa. Utilizou-se a pesquisa qualitativa e entrevistas abertas aplicadas para 115 mães, beneficiárias do Programa Bolsa Família, de Mafra, São Bento do Sul, Três Barras e Irineópolis. Constatou-se que os participantes do estudo compreendiam a pobreza a partir de uma visão multidimensional, pela qual a ausência de renda não é o único fator considerado como provocador desta condição de forma que os elementos identificados reforçam a visão de que o desenvolvimento da região também está relacionado ao envolvimento social de seus sujeitos, permitindo que estes possam sentir-se ativos no processo de crescimento pessoal, social e das regiões onde vivem. No escopo do desenvolvimento e, por conseguinte, do desenvolvimento regional, este deve compor a agenda política de uma sociedade, na qual deve prioritariamente ser discutido e refletido o desenvolvimento pelos âmbitos sociais, políticos, culturais e ambientais de uma determinada sociedade.
\end{abstract}

Palavras Chaves: Pobreza. Representações Sociais. Desenvolvimento do Planalto Norte Catarinense.

\footnotetext{
${ }^{1}$ Possui graduação em Serviço Social pela Faculdade Espírita do Curitiba (1992), mestrado em Educação pela Universidade Federal de Santa Maria (1999) e doutorado em Serviço Social pela Pontifícia Universidade Católica de São Paulo (2004). Atualmente é professora titular da Universidade do Contestado. Santa Catarina. Brasil. E-mail: marialuiza@unc.br

${ }^{2}$ Docente da Universidade do Contestado, curso de Psicologia e Mestre em Desenvolvimento Regional. Universidade do Contestado. Santa Catarina. Brasil. E-mail: pollyana@unc.br
} 


\title{
THE SOCIAL REPRESENTATIONS AND THE IMPLICATIONS OF POVERTY IN THE DEVELOPMENT OF THE NORTH CATARINIAN PLANTATION
}

\begin{abstract}
The objective of this study was to analyze the social representations of the subjects living in poverty in the North Plateau of Santa Catarina. Attended 115 mothers, aged between 18 and 63 years, all beneficiaries of the Family Grant Program, residents in the municipalities of Mafra, São Bento do Sul, Três Barras and Irineópolis. It was noted that study participants understood poverty from a multidimensional vision, in which the absence of income is not the only factor considered provocative of this condition so that the elements identified reinforce the view that the development of the region is also related to social involvement of their subject, allowing them to make and active in the process of personal growth social, and of the regions where they live. In the scope of development and consequently on regional development, this should compose the political agenda of a society, which should primarily be discussed and reflected the development by social, political, environmental and cultural of a given society.
\end{abstract}

Keywords: Poverty. Social Representations. Development of the Plateau North of Santa Catarina.

\section{INTRODUÇÃO}

Este texto trata da representação social dos sujeitos pobres atendidos pelo Programa Bolsa Família no Planalto Norte Catarinense e os desafios que este representa para o desenvolvimento nessa região. É possível considerar que a problemática da pobreza tem atraído atenção e preocupações em nível mundial, de forma que estudos sobre a desigualdade de renda, a inclusão e exclusão social têm se mostrado temas cada vez mais centrais. A pobreza e a desigualdade social contêm índices que sempre se fizeram presentes no processo histórico da sociedade de forma recorrente. No contexto da pobreza e da exclusão, as discussões apresentavam-se desafios que nos dias de hoje são considerados problemas sociais, para serem enfrentados pelos governos e pela própria sociedade, tal como o que ocorre na região sobre a qual se desenvolveu este estudo.

A região do Planalto Norte Catarinense é composta pelos municípios de Bela Vista do Toldo, Canoinhas, Irineópolis, Itaiópolis, Mafra, Major Vieira, Monte Castelo, Papanduva, Porto União e Três Barras ${ }^{3}$. Essa região comporta aproximadamente 357.039 habitantes (IBGE, 2010) e o Índice de Desenvolvimento Humano (IDH) oscila entre o município de Porto União com 0,786, o mais alto e Matos Costa, que apresenta o IDH-M mais baixo de 0,657 .

Esse cenário é a representação para a sociedade do que é não ter emprego ou ter um trabalho mal remunerado, possuir uma casa sem capacidades para satisfazer as necessidades básicas, não trazem apenas carência de recursos e impossibilidade de adquirir bens de

${ }^{3}$ Trata-se do recorte que abrange os municípios da Associação dos Municípios do Planalto Norte Catarinense. 
consumo; mas trazem também ao próprio indivíduo sensação de inutilidade, incapacidade de se realizar, sensação esta, que impede os indivíduos de usufruírem das benesses do mundo. É a partir desta percepção que se entende a necessidade de estudar a pobreza e a exclusão social.

Para tanto, este estudo teve como direção a questão acerca de quais são as representações sociais que emitiram os sujeitos que viviam em condição de pobreza no Planalto Norte Catarinense e que desafios representavam para a região? Assim, o objetivo geral do estudo foi o de analisar as representações sociais acerca da condição de pobreza que os pesquisados do Planalto Norte Catarinense viviam como representações sociais que podem sustentar desafios ao desenvolvimento da região.

O texto deste é descrito na seguinte ordem: em um primeiro momento é apresentado o referencial teórico estruturado com os principais temas que abrangem este estudo, no segundo momento os procedimentos metodológicos para a sua construção são descritos, para proporcionar entendimento dos resultados e discussão que são apresentados em um terceiro momento e por fim, este estudo concluí-se com a apresentação das considerações finais.

\section{DESENVOLVIMENTO REGIONAL}

Da mesma forma que o tema da pobreza, o tema do desenvolvimento caracteriza-se por ser uma questão ampla que vem sendo discutida no Brasil desde o final da década de 1970, com o propósito de organizar a população e identificar fatores que contribuíram para o desenvolvimento. Neste aspecto, o desenvolvimento deve ser discutido e refletido pelos âmbitos econômicos, políticos, culturais e ambientais de uma determinada sociedade e território (DALLABRIDA, 2004).

As mudanças ocorridas principalmente no processo de globalização provocaram uma transição no entendimento do conceito de desenvolvimento, gerando discussões que envolveram a sociedade e o Estado em busca de conceitos que apontassem a relação entre estas partes. A partir deste ponto é possível identificar que as discussões dos autores articuladores destas relações integrando-as ao processo de desenvolvimento.

Já Cabugueira (2000), aponta que assim como a região pode ser vista como uma entidade real, objetiva e concreta de fácil identificação, pode também ser vista como uma ideia e um modelo para diferenciar espaços territoriais afim de facilitar análises e estudos técnicos ${ }^{4}$.

Para Diniz (2002) é por meio do desenvolvimento que se busca as melhorias das sociedades a partir da melhoria da condição de vida das pessoas que fazem parte dos grupos. Este autor aponta que "[...] o desenvolvimento impõe autoconhecimento com o fim de

\footnotetext{
${ }^{4}$ Para complementar o esclarecimento Cabugueira (2000) faz uma distinção entre espaço e região apontando que espaço pode ser definido a partir de um conjunto de dados econômicos onde a sua unidade é definida por sua natureza e relações de interdependência, já a região é definida de forma mais restrita não resultando de fatores associados à dimensões, mas a razões de contiguidade, onde os elementos que a compões tem de localizar-se necessariamente de forma mais aproximada.
}

DRd - Desenvolvimento Regional em debate (ISSNe 2237-9029)

v. 6, n. 3, p. 235-260, nov. 2016. 
implementar ações, o que pressupõe a motivação dos participantes com o fim de propor em marcha um processo de mudança" (p.1).

O autor Boisier (1996), escreve que o conceito de desenvolvimento está em fase de transição, mudando da concepção relacionada diretamente com o crescimento econômico e com as conquistas materiais advindas das satisfação dos indivíduos sociais para uma concepção que entende o desenvolvimento como um processo intangível e subjetivo, relacionado mais a atitudes do que a conquistas. Este autor apresenta um conceito contemporâneo para o desenvolvimento regional quando escreve que:

Uma concepção atualizada e contemporânea do desenvolvimento regional leva a reconhecer que se trata de um processo em curso com três cenários independentes e de recente reconfiguração: há um cenário contextual, um cenário estratégico e um novo cenário político. (BOISIER, 1996, p.113).

O cenário contextual então pode ser explicado pela interação entre o processo de abertura externa ${ }^{5}$ impulsionado pela globalização e o processo de abertura interna ${ }^{6}$ impulsionado pela descentralização. Este conceito descreve o território sem intervenção humana, já o cenário estratégico é explicado a partir de uma visão administrativa de gestão da região que a define como quase estado com o objetivo de colocar a dimensão política em primeiro lugar. Boisier (1996) justifica esta condição a partir da explicação que as regiões encontram-se articuladas entre si por uma relação de dominação e dependência ${ }^{7}$.

O terceiro cenário utilizado para repensar o desenvolvimento regional é o cenário político que é constituído sob a interseção do processo de modernização do Estado e das novas funções dos governos territoriais.

Sobre isso Boisier (1996, p.126) destaca:

O tema modernização do estado já se tornou recorrente no discurso político e acadêmico de toda a América Latina. Entretanto não deixam de surpreender, de um lado, o enfoque reducionista de certas posições que tomam a modernização como mera redução e o enfoque simplista de outro, em afirmações que consideram a modernização como mera redução do Estado como uma questão puramente tecnocrática, vinculada a informatização, eficiência procedimental e administração de pessoal.

Sendo assim são muitos os motivos que promovem o interesse no desenvolvimento regional, seja ele intelectual ou político.

${ }^{5}$ O processo de abertura externa é provocado pela globalização e pode ser medida e avaliada na
qualquer momento. É através da abertura externa que qualquer país possui o objetivo de se
enquadrar em dois espaços do comércio internacional, na modernidade que significa vender
produtos e/ou serviços com elevado conteúdo e desenvolvimento técnico e na competitividade que
significa possuir capacidade para aumentar as vendas sistematicamente ampliando sua participação
no mercado apresentando condições de expansão (BOISIER, 1996).
${ }^{6}$ O processo de abertura interno é impulsionado pela descentralização, que traz consigo um processo
político de abertura interna que se apresenta por meio de quatro elementos, a revolução científica e
tecnológica, comunicação e transporte. Este processo tem como objetivo distribuir os lucros
advindos da abertura externa de modo equitativo, conferindo a população um papel mais efetivo nas
definições de opções políticas relacionadas a cada escala territorial (BOISIER, 1996).
7 Para Boisier (1996) a relação de dominação e dependência impedia o desenvolvimento da região de
forma que se uma região quisesse se desenvolver precisaria primeiro romper esta relação
substituindo-a por uma relação cooperativa. 238

DRd - Desenvolvimento Regional em debate (ISSNe 2237-9029)

v. 6 , n. 3, p. 235-260, nov. 2016. 
A partir deste ponto, duas perspectivas podem ser discutidas, uma que aponta as tendências políticas e econômicas que constantemente provocam mudanças na geografia política evidenciando cada vez mais a necessidade de uma descentralização política e territorial. E a outra que reconhece a importância da relação direta entre a realização do projeto de vida de cada indivíduo e o comportamento do entorno em que ele vive.

Este estudo, portanto, pauta-se nestas perspectivas uma vez que trata das representações sociais dos sujeitos pobres e sua relação com o desenvolvimento da região que vivem. Logo busca explicar a inter-relação existente entre a visão econômica e política, com a visão individual de desenvolvimento dos sujeitos impulsionados ou não pelo território que vivem.

O estudo foca então o território sobre o qual refletirá o seu desenvolvimento, no Estado de Santa Catarina, localizado no Planalto Norte Catarinense.

\section{POBREZA}

A pobreza pode ser entendida sob diversos aspectos, como privação em termos de materiais, na forma de fome ou na baixa qualidade de moradia. Tratando-se de termos econômicos, pode ser entendida sob forma de inadequação de renda e em termos sociais é definida como isolamento da comunidade ou sentimento de baixa autoestima (VINHAS, 2006).

Esta problemática tem alcançado patamares cada vez mais elevados em todo o mundo; no Brasil nas últimas décadas vem se observando cada vez mais desigualdade na distribuição de renda e significativos níveis de pobreza (SILVA; BANDEIRA; LOPES, 2011). Logo, explicar este fenômeno exige um esforço para o seu entendimento no campo das determinações sociais.

Para melhor entendimento sobre o fenômeno pobreza faz-se necessária a identificação de abordagens que o descrevem. A literatura especifica identifica quatro abordagens fundamentais para sua compreensão no âmbito social, sendo as elas: as culturalistas; as estruturalistas; as liberais-neoliberais; e, as abordagens que concebem a pobreza como fenômeno multidimensional (SILVA, 2004).

As abordagens culturalistas da pobreza concebem-na como decorrência de fatores internos, comportamentais e valorativos defendidos pelos pobres, nos quais o fator cultural é entendido como único determinante da pobreza no mundo. Oscar Lewis (1983) um dos principais defensores desta teoria é citado por Paugam (2003, p. 51): 
vivem. [...]. A cultura da pobreza não é somente uma adaptação a uma série de condições objetivas do conjunto da sociedade. Uma vez que se manifeste, tende a se perpetuar de geração em geração, em razão do efeito que produz nas crianças. Quando as crianças dos cortiços atingem seis ou sete anos, em geral já assimilaram os valores básicos e os hábitos de sua sub-cultura, e não se encontram em condições psicológicas para aproveitar plenamente a evolução ou os progressos possíveis de acontecer durante sua vida.

Este tipo de concepção tem sido adotado no Brasil como base para a elaboração de políticas públicas de enfrentamento da pobreza desde os anos de 1970. Já as abordagens estruturalistas, cuja discussão predominava nos anos de 1950, se posicionam inversamente as abordagens culturalistas, uma vez que se concentra nas explicações sobre a pobreza em fatores externos e estruturais, entendendo o comportamento dos pobres como consequência e não como causa da pobreza (JESUS; COSTA, 2007).

\begin{abstract}
A tese estrutural, consequentemente opera uma mudança de perspectiva: se os mais desfavorecidos são afastados temporária ou definitivamente do mercado de trabalho e das instituições oficiais, isso não ocorre porque se desinteressam pelos valores da sociedade em geral, mas porque na ausência de renda estável, de poder e de instrução, reconhecem que suas chances de promoção social são comprometidas e que estão condenados a viver por mais ou menos tempo em um contexto cultural no limite da exclusão social (PAUGAM, 2003, p.52).
\end{abstract}

Esta vertente explicativa encontra suas bases no campo marxista que concebe e explica a sociedade capitalista pelos processos de exploração do capital sobre o trabalho.

Já a abordagem liberal-neoliberal dos anos de 1970 converge com a culturalista apresentada anteriormente. Identifica as causas da pobreza e não concorda com intervenções realizadas pelo Estado sobre a pobreza. Essa teoria aponta que essa intervenção interferiu na liberdade de cada individuo para suprir suas necessidades a partir de suas próprias escolhas.

Para essa abordagem a intervenção do Estado sobre a pobreza poderia desestimular o individuo buscar no trabalho a condição de interação social. Ou seja, para os liberais ditos ortodoxos, não deveria ocorrer nenhuma intervenção do Estado sobre a pobreza e qualifica o pobre como aquele indivíduo incapaz de competir no mercado. Por outro lado, um segundo grupo aceitou a necessidade de uma intervenção do Estado, desde que fosse pontual e em circunstâncias bem definidas (SILVA, 2000).

Por fim, a abordagem da pobreza enquanto fenômeno multidimensional provoca a discussão que defende o conceito de pobreza de forma complexa, podendo ser levado em conta juízos de valor em termos relativos ou absolutos. Crespo e Gurovitz (2002, p.3) descrevem que "[...] a pobreza pode ser estudada apenas do ponto de vista econômico ou incorporada a aspectos não econômicos à análise, sendo contextualizada de forma dependente ou não da estrutura sócio política da sociedade". Esta abordagem tem como proposta central contestar as concepções que apresentam uma visão homogênea e dicotômica da pobreza.

A abordagem multidimensional define a pobreza a partir de três esferas que se interrelacionam: a pobreza como juízo de valor, a pobreza relativa e a pobreza absoluta (SILVA, 2007).

Crespo e Gurovitz (2002, p. 3) dizem que a pobreza como juízo de valor, 
[...] quando se trata de uma visão subjetiva, abstrata, do indivíduo, acerca do que deveria ser um grau suficiente de satisfação de necessidades, ou do que deveria ser um nível de privação normalmente suportável. O indivíduo expressa sentimentos e receitas, de caráter basicamente normativo, do que deveriam ser os padrões contemporâneos da sociedade quanto à pobreza. Não leva em conta uma situação social concreta, objetivamente identificável, caracterizada pela falta de recursos. Desse modo, tal enfoque não esconde sua fragilidade, embora seja bastante óbvio que mesmo uma conceituação objetiva da pobreza não se furta à presença de algum juízo de valor.

Silva (2000) descreve que a concepção de pobreza a partir de um juízo de valor, por vezes pode dar base à interpretação empírica do fenômeno, defendendo que a compreensão a partir de uma visão dualista pode explicar melhor as manifestações empíricas da pobreza. Ainda, esta autora aponta que a noção de insuficiência dos níveis de vida e a de desigualdade na distribuição de renda sustenta a explicação mais frequentemente utilizada para esclarecer a pobreza, a partir das definições de pobreza absoluta e pobreza relativa.

Crespo e Gurovitz (2002) ao descreverem que as percepções de pobreza relativa se fazem a partir do cunho macroeconômico, assim como o conceito de pobreza dizem que:

A pobreza relativa tem relação direta com a desigualdade na distribuição de renda. É
explicitada segundo o padrão de vida vigente na sociedade que define como pobres
as pessoas situadas na camada inferior da distribuição de renda, quando comparadas
àquelas melhor posicionadas. O conceito de pobreza relativa é descrito como aquela
situação em que o indivíduo, quando comparado a outros, tem menos de algum
atributo desejado, seja renda, sejam condições favoráveis de emprego ou poder. Já o
enfoque absoluto na conceituação da pobreza se observa quando da fixação de
padrões para o nível mínimo ou suficiente de necessidades, conhecido como linha
ou limite da pobreza, determinando a percentagem da população que se encontra
abaixo desse nível. Esse padrão de vida mínimo, apresentado sob diferentes
aspectos, sejam nutricionais, de moradia ou de vestuário, é normalmente avaliado
segundo preços relevantes, calculando a renda necessária para custeá-los (CRESPO;
GUROVITZ, 2002, p. 03-04)

O enfoque de pobreza absoluta é utilizado, portanto, como um instrumento para a concepção de intervenções do Estado que fixa padrões para o nível mínimo ou suficiente de necessidades dos indivíduos, padrão conhecido como linha ou limite de pobreza que determina o percentual da população que se encontra abaixo deste nível.

Vinhas (2006) descreve que para o estabelecimento dos limites de pobreza são considerados três enfoques. O enfoque biológico define a pobreza a partir de requisitos nutricionais mínimos da dieta alimentar; o enfoque das necessidades básicas considera a alimentação, a moradia, vestuário e serviços essenciais de água, saneamento, transporte público, serviços médicos e de educação como necessários; e o ultimo enfoque definem a ideia do salário mínimo que defende a ideia de um salário mínimo inicial deva ser dinheiro necessário para suprir um nível de vida mínimo.

Já a definição de pobreza relativa se mantém a partir da noção de desigualdade e da ausência de condições que permite aos pobres participarem de um padrão mínimo de sobrevivência oferecido, com um padrão de renda que atenda às condições mínimas de vida para o indivíduo (SILVA, 2000). 
Considerando essas diferentes abordagens sobre pobreza no decorrer do século XX três novas concepções foram desenvolvidas: a concepção de sobrevivência, de necessidades básicas e de privação relativa.

Durante os séculos XIX e XX até a década de 1950 o enfoque de sobrevivência predominou. Teve origem no trabalho de nutricionistas inglesas que apontavam que a renda do mais pobre não era suficiente para a manutenção do rendimento físico de um indivíduo. Este enfoque tinha como objetivo preservar a ênfase no individualismo compatível com o ideário da teoria liberal (apresentada acima neste estudo). A partir deste ponto de vista e com a utilização de medidas estatísticas formulou-se o primeiro modelo de proteção social para o Estado de bem estar fundamentado em políticas nacionais de assistência (SILVA, 2007).

A partir de 1970, novas exigências como serviços de água potável, saneamento básico, saúde, educação e cultura passaram a ser consideradas necessidades mínimas para a sobrevivência e por esta razão a pobreza recebeu a conotação relacionada com as necessidades básicas (PEREIRA-PEREIRA, 2000).

Rocha (2006, p. 19) expõe que a adoção da “[...] abordagem de necessidades básicas insatisfeitas significa ir além daquelas de alimentação para incorporar uma gama mais ampla de necessidades humanas, tais como educação, saneamento, habitação", em contingencia com os direitos sociais previstos pela Constituição Federal Brasileira de 1988. Por esta razão a noção de pobreza abrange outros aspectos da vida cotidiana dos sujeitos, considerando que estas não só se alimentam como também se relacionam e trabalham.

Somente nos anos de 1980 é que a pobreza foi vista por outro enfoque mais abrangente e rigoroso, com maior direcionamento para se definir as interferências sobre a pobreza, que passou a ser entendida como privação relativa. Este conceito introduziu ao estudo da pobreza variáveis mais amplas que a conduziram para o entendimento de que os sujeitos podem sofrer privações em diversas esferas da vida, não implicando somente na privação material e que estas privações sofridas pelas pessoas determinam o seu posicionamento em todas as esferas sociais (CRESPO; GUROVITZ, 2002).

Outra forma de se entender a pobreza e que ampara a estruturação do presente estudo é a citada por Silva (2007). Esta autora considera a pobreza enquanto expressão objetiva ou subjetiva. A primeira expressão se refere às manifestações concretas do fenômeno na vida dos pobres; por outro lado, a dimensão subjetiva da pobreza diz respeito ao como o fenômeno é percebido pela sociedade em geral, inclusive pelos próprios sujeitos da pobreza.

Conforme Silva (2007) a pobreza é perceptível em diversos lugares e situações; captar sua dimensão é complexo e subjetivo, uma vez que ela apresenta uma multidimensionalidade, podendo ser explicada de forma absoluta, relativa e subjetiva.

Um dos parâmetros mais conhecidos para a determinação da pobreza e que indica a pobreza extrema é o parâmetro estabelecido pelo Banco Mundial, o qual estabelece que são pobres extremos os que vivem com menos de 1 dólar por dia. Este parâmetro é criticado por atender uma perspectiva limitada da problemática, ou seja, mensura renda e consumo na perspectiva econômica, uma vez que a pobreza vem se mostrando cada vez mais multifacetada.

DRd - Desenvolvimento Regional em debate (ISSNe 2237-9029) 
Em complemento aos critérios e situações da pobreza e da pobreza extrema no Brasil, apontados no início deste estudo, o IBGE identificou também que a predominância da população nestas condições localizava-se no meio rural e que os estados do nordeste concentram a maior parte dos sujeitos extremamente pobres (9,61 milhões); a região sudeste possui 2,72 milhões de sujeitos nestas condições, seguido pelo norte com um contingente de 2,65 milhões; no sul são 715,96 mil sujeitos em condições de extrema pobreza (IBGE, 2010).

A criação de um indicador que sintetizasse a pobreza em suas mais diversas dimensões surgiu no ano de 1990 pelo Programa das Nações Unidas para o Desenvolvimento (PNUD) e denominou-se Índice de Pobreza Humana (IPH) no ano de 1997. Este índice tem sido utilizado desde então em estudos sobre o desenvolvimento humano (IPEA, 2007).

A definição e respectiva caracterização de desenvolvimento humano têm por objetivo aferir o avanço da qualidade de vida de uma população considerando suas características econômicas, culturais, sociais e políticas. Esta abordagem procura focar diretamente para as pessoas, suas oportunidades e capacidades.

A partir da definição do Índice de Desenvolvimento Humano (IDH), criado pela Organização das Nações Unidas (ONU) para avaliar a qualidade de vida e o desenvolvimento econômico da população. Este índice varia de zero (quando não apresenta nenhum desenvolvimento) até 1 (hum), (quando é considerado que há desenvolvimento humano total). Por este parâmetro, é elaborado relatório sobre o desenvolvimento humano de 187 países, pelo Programa das Nações Unidas (PNUD). No ano de 2013 o Brasil manteve-se nesse ranking mundial no $85^{\circ}$ lugar apresentando o IDH de 0,73 (PNUD, 2013). O Brasil nas últimas décadas veio demonstrando tendência de aprofundamento da desigualdade pela distribuição de renda gerando elevados níveis de pobreza.

A desigualdade social em especial carrega consigo a pobreza como condição social e historicamente produzida, porém, o enfrentamento da pobreza que faz parte das estratégias da superação da desigualdade vêm por meio da transferência de renda, que no Brasil é prevista por programas sociais, tais como o Programa Bolsa Família (PBF).

O PBF é um programa de transferência de renda direta para as famílias, vinculado a um auxilio financeiro para as que encontram-se em condições de pobreza extrema. Desta forma a seleção das famílias para receberem o benefício do PBF se dá pela sua inclusão no cadastro único para programa Socais (CadÚnico) que é preenchido nos municípios, utilizando-se de uma ferramenta eletrônica. A partir dos dados cadastrados, o Ministério do Desenvolvimento Social seleciona sistematicamente as famílias que serão incluídas no PBF.

No estado de Santa Catarina encontram-se 134.132 famílias beneficiadas pelo PBF, destas 4.501 famílias (3,35\%) fazem parte do recorte amostral deste estudo por pertencem aos municípios estudados (Mafra, São bento do Sul, Irineópolis e Três barras) ${ }^{8}$.

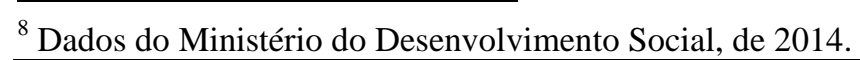




\title{
REPRESENTAÇÕES SOCIAIS
}

A definição de representação social ${ }^{9}$ vem sendo discutida com mais frequência a partir dos últimos 40 anos. Um dos fatores desencadeadores dessa discussão pode ser atribuído ao interesse em estudos acerca de fenômenos de domínio simbólico. Mesmo com a emergência de outros conceitos oriundos da sociologia em busca de uma definição deste simbólico, é na psicologia social que a representação social vem sendo fundamentada teoricamente, a partir de Serge Moscovicci ${ }^{10}$ (ARRUDA, 2002). A psicologia social aborda as representações sociais a partir da relação sujeito sociedade, acreditando que os indivíduos, grupos e sociedade constroem seus conhecimentos a partir de uma inscrição social e cultural.

Alves-Mazzotti (2008, p. 21) conceitua representações sociais, dizendo que:

\begin{abstract}
Nas sociedades modernas, somos diariamente confrontados com uma grande massa de informações. As novas questões e os eventos que surgem no horizonte social frequentemente exigem, por nos afetarem de alguma maneira, que busquemos compreendê-los, aproximando-os daquilo que já conhecemos, usando palavras que fazem parte de nosso repertório. Nas conversações diárias, em casa, no trabalho, com os amigos, somos instados a nos manifestar sobre eles procurando explicações, fazendo julgamentos e tomando posições. Estas interações sociais vão criando "universos consensuais" no âmbito dos quais as novas representações vão sendo produzidas e comunicadas, passando a fazer parte desse universo não mais como simples opiniões, mas como verdadeiras "teorias" do senso comum, construções esquemáticas que visam dar conta da complexidade do objeto, facilitar a comunicação e orientar condutas.
\end{abstract}

As produções teóricas de Moscovicci surgem em 1961, na França, produzindo impacto nos meios sociais devido a seu direcionamento e principalmente por contrariar o behaviorismo, paradigma dominante da Psicologia que buscava na época através da experimentação estabelecer o que era cientifico.

O direcionamento teórico de Moscovicci era para fenômenos marcados pelo subjetivismo, que possuíam metodologias ainda diferentes do que se considerava ciência na época, que dependia da interpretação do pesquisador para a sua análise (ARRUDA, 2002).

Moscovicci (2003, p.172) descreve que:

A teoria das representações sociais é singular, parece-me devido ao fato de esta teoria tender mais e mais, na direção de se tornar uma teoria geral dos fenômenos sociais e uma teoria especifica dos fenômenos psíquicos. Este paradoxo não se da

\footnotetext{
${ }^{9}$ A psicologia social aborda as representações sociais no âmbito do seu campo, do seu objeto de estudo, da relação indivíduo-sociedade e de um interesse pela cognição, embora não situado no paradigma clássico da psicologia. Esta abordagem se reflete sobre como os indivíduos, os grupos, os sujeitos sociais, constroem seu conhecimento a partir da sua inscrição social, cultural, de forma a se compreender como a sociedade se dá a conhecer e constrói esse conhecimento com os indivíduos.

${ }^{10}$ Romeno naturalizado francês Serge Moscovici é dono de uma obra considerável, tão importante para a psicologia (seu campo de formação e atuação) como para a história e as ciências sociais. Seus trabalhos e sua teoria das representações sociais (TRS) têm influenciado ao longo das últimas quatro décadas pesquisadores tanto na Europa como nas Américas, incluindo o Brasil. Entre sua vasta obra - doze livros individuais e quatorze que ele organizou ou escreveu em conjunto com outros autores -, apenas dois foram traduzidos para o português.
} 
por acaso, ele provem da natureza profunda das coisas. É uma teoria geral a medida que dentro do que lhe compete uma sociedade não poderia ser definida pela simples presença de um coletivo que reuniu indivíduos através de uma hierarquia de poder por exemplo, ou através de intercâmbios baseados em interesses mútuos.

Pode-se entender então que as teorias das representações sociais operacionalizam um conceito para se analisar com o pensamento social em sua dinâmica e em sua diversidade.

Ainda Moscovicci juntamente com Nemeth (1974, apud MOSCOVICCI, 2003), afirmam que as representações sociais são conjuntos dinâmicos que provocam a produção de comportamentos e relações como meio de modificar o outro, de forma lógica, própria, em uma linguagem particular não se transformando nem em opiniões sobre objetos ou imagens, mais sim teorias ou ciências coletivas que se destinam a interpretação da realidade atual.

Desta forma o estudo das representações sociais provoca uma releitura do saber popular, de forma que o conhecimento sobre a realidade torne-se socialmente construído.

A partir desta perspectiva vê-se a importância de estudar as representações sociais a partir da vivencia de sujeitos que se encontram em condição de pobreza e extrema pobreza. Identificando o papel das políticas públicas neste cenário a partir do desenvolvimento de programas sociais. Considerando então que o entendimento de pobreza relaciona-se a algum tipo de privação seja ela material, cultural ou social em face aos recursos disponíveis de um sujeito, vê-se a necessidade de maior exploração deste universo científico uma vez que entende-se importante que o sujeito reconhecido como pobre possa contribuir com estes dados de forma que o mesmo aponte pelo seu discurso as características da exclusão social que sofre.

A exclusão social historicamente produzida no Brasil, deste a época do Brasil Colônia, passou a ser mais observada a partir da década de 1970, momento em que foi relacionada com o crescimento econômico brasileiro. Sendo assim estudar a pobreza mostra-se relevante tanto para fins científicos, como para identificar políticas públicas, ou mesmo constituir novas políticas públicas que objetivem o enfrentamento da exclusão. Este estudo ainda é relevante para entender os fins sociais na busca por uma condição mais justa e humana para a garantia dos direitos a todas as pessoas, indiferente de sua condição econômica e social. É neste contexto, que o presente estudo busca contribuir para um melhor entendimento sobre as representações sociais dos indivíduos que vivem em condição de pobreza no Planalto Norte Catarinense.

\section{MATERIAIS E MÉTODOS}

A pesquisa foi desenvolvida na região denominada Planalto Norte Catarinense, na qual vivem 357.039 habitantes (IBGE, 2010), composta pelos municípios de Bela Vista do Toldo, Canoinhas, Irineópolis, Itaiópolis, Mafra, Major Vieira, Monte Castelo, Papanduva, Porto União e Três Barras. Desse universo, foram definidos quatro municípios para a pesquisa de campo tendo-se como critério de definição, serem os dois municípios de maior IDH - M regional e dois de menor IDH - M regional. 
Participaram deste estudo 115 mulheres com idade entre 18 e 63 anos, dos municípios de São Bento do Sul (N-31), Mafra (N-36), Irineópolis (N-18) e Três Barras (N-30). Essa amostra foi constituída por mães inscritas no Programa Bolsa Família desses quatro municípios, integrantes dos grupos do Programa de Convivência e Fortalecimento de Vínculos dos Centros de Referências de Assistência Social (CRAS), no mês de setembro do ano de 2013. Como critério de inclusão utilizou-se a assinatura no Termo de Consentimento Livre e Esclarecido.

Das 115 entrevistadas, 91,29\% possuíam escolaridade de até o primeiro grau concluído, fator que julgam ser o influenciador da dificuldade de inserção no mercado de trabalho. Somente $23,47 \%$ destas mães encontravam-se inseridas no mercado de trabalho, ainda que informal.

Todas as pesquisadas para este estudo, beneficiárias do Programa Bolsa Família (principal programa de transferência de renda desenvolvido pelo estado para enfrentar a pobreza e a pobreza extrema) tinham renda per capta de inferior a (1) salário mínimo $(33,04 \%, \mathrm{R} \$ 724,00)$ e $66,96 \%$ recebiam renda de hum (1) salário mínimo.

Tabela 1 - Apresentação dos participantes do estudo

\begin{tabular}{l|c|c|c}
\hline $\begin{array}{c}\text { Municípios } \\
\text { participantes do estudo }\end{array}$ & $\begin{array}{c}\text { Participantes do encontro } \\
\text { no dia da coleta de dados }\end{array}$ & $\begin{array}{c}\text { Participantes } \\
\text { beneficiários convidados } \\
\text { para participar }\end{array}$ & $\begin{array}{c}\text { Participantes beneficiários } \\
\text { que aceitaram participar }\end{array}$ \\
\hline São Bento do Sul & 52 & 49 & $31(63,26 \%)$ \\
\hline Mafra & 48 & 41 & $36(87,80 \%)$ \\
\hline Irineópolis & 33 & 25 & $18(72 \%)$ \\
\hline Três Barras & 40 & 35 & $30(85,71 \%)$ \\
\hline \multicolumn{2}{r}{} \\
\hline
\end{tabular}

Fonte: Dados do estudo (2014)

O estudo desenvolvido foi orientado pelos procedimentos metodológicos da abordagem qualitativa e explicativa. A pesquisa de campo foi desenvolvida pela aplicação de uma entrevista semi dirigida para mulheres, conforme amostragem descrita acima. O roteiro da entrevista era composto por sete (7) perguntas e o local da coleta de dados foi a residência dos sujeitos, quando de visita realizada pela pesquisadora durante os meses de agosto a outubro de 2014. A entrevista teve duração média de 30 minutos e foi realizada em local da casa escolhido pelo pesquisado. Este cuidado foi tomado em virtude de a gravação das respostas não fosse afetada. Para a análise dos dados deste estudo utilizou-se como procedimento metodológico a análise do discurso do sujeito coletivo (LEFÈVRE; LEFÈVRE; TEIXEIRA, 2000). 


\section{RESULTADOS E DISCUSSÃO}

A pobreza é destacada no Brasil pelos estudos, meios de comunicação, dados e indicadores socioeconômicos, os quais divulgam este problemática oriunda de uma sociedade que é organizada em classes sociais. São diversas as justificativas apresentadas à condição de pobreza e miséria vivida por mais de 16,27 milhões de pessoas no Brasil, o equivalente a 8,5\% da população (IBGE, 2010). Entre elas podemos citar, por um lado, à responsabilidade social do Estado; por outro lado, ao histórico e estrutural desemprego, à baixa escolaridade, escassas oportunidades para capacitação profissional e à exclusão de classes. Uma terceira questão ainda refere-se ao próprio sujeito que apresenta baixa estima, desvalorização pessoal, falta de confiança do sujeito e da própria sociedade sobre ele.

O IBGE revelou que no ano de 2013, daqueles 16,27 milhões de brasileiros que viviam em condição de extrema pobreza, 4,8\% não possuíam nenhuma renda e, os demais 11,4 milhões possuíam rendimento per capita de $\mathrm{R} \$ 1,00$ a $\mathrm{R} \$ 70,00$.

Em linhas gerais a pobreza é entendida como estado de privação de um sujeito cujo bem estar é inferior ao mínimo que sua sociedade é obrigada a garantir. Sendo assim, a pobreza pode se expressar por meio de muitas formas e seu crescente desenvolvimento pode ser acompanhado no mundo todo. Daí a importância de se buscar cada vez mais entender e explicar a problemática que se faz presente também no recorte territorial do Planalto Norte Catarinense.

No Brasil, a linha da pobreza estipula que são consideradas extremamente pobres as famílias com renda per capita de até $\mathrm{R} \$ 70,00$ (setenta reais) e sob esse parâmetro são elaboradas políticas públicas de enfrentamento a pobreza. A região sobre a qual se desenvolveu o estudo e a pesquisa (Planalto Norte Catarinense) da população total (357.039 habitantes, IBGE, 2010), 41.954 (11,75\%) são de famílias em vulnerabilidade social devido a condições que estão expostas. Portanto, são 9.968 habitantes $(2,70 \%)$ que se encontram em extrema pobreza (renda per capta menor de R \$ 70,00 mês).

É neste contexto que se inserem as políticas públicas de assistência social que dentre seus programas e ações promovidas destaca-se que o objetivo do Estado brasileiro é o de minimizar e de erradicar a fome, a pobreza e a desigualdade social. Frente às discussões acima apresentadas verifica-se cada vez mais que o aumento da pobreza nas sociedades capitalistas decorre de mudanças em seus padrões de desenvolvimento, quando os programas de transferência de renda (desenvolvidos a partir de política pública) apresentam-se como estratégia do Estado para enfrentar a pobreza. Por isso, para este estudo o Programa Bolsa Família serviu como um dos determinantes da amostragem que selecionou os sujeitos pobres a partir do mesmo critério estabelecido pelo Estado. O Planalto Norte Catarinense apresentou, no estudo realizado, um total de 34.612 famílias inscritas no PBF, atingindo um percentual de 9,69\% da população total da região.

Considerando características sociais e demográficas pode-se identificar que 50,43\% (N-58) possuíam escolaridade de $1^{\circ}$ grau incompleto, 40,86\% $(\mathrm{N}-47)$ possuíam o $1^{\circ}$ grau completo, $7,82 \%(\mathrm{~N}-9)$ possuíam o $2^{\circ}$ grau incompleto e nenhuma participante possuía o $2^{\circ}$ grau completo ou qualquer curso técnico ou profissionalizante. 
Em outra questão identificou-se a relação dos participantes do estudo com o mercado de trabalho, mostrando que $23,47 \%(\mathrm{~N}-27)$ encontram-se ativos no mercado de trabalho informal, 76,53\% (N-88) relatam encontrarem-se fora do mercado de trabalho seja ele formal ou informal e $0 \%$ dos participantes referem estarem ativos no mercado de trabalho formal.

Devido ao estudo tratar de famílias beneficiárias do Programa Bolsa Família e os sujeitos do estudo tratarem-se de mães, levantou-se também o número de integrantes nas famílias estudadas, de forma que foi possível apontar que 33,91\% (N-39) dos participantes possuem famílias compostas com até 3 integrantes, 45,21\% (N-52) dos participantes possuem famílias compostas por 4 ou 5 integrantes e $20,86 \%$ (N-24)possuem famílias compostas com mais de 6 integrantes.

No que se refere à renda per capta das pesquisadas, identificou-se que 66,95\% (N-77) possuem renda per capta de 1 salário mínimo, 33,05\% (N-38) referem possuir renda per capta inferior a 1 salário mínimo e $0 \%$ das participantes referem possuir renda superior a 1 salário mínimo.

Os questionamentos realizados em toda entrevista apresentaram respostas bastante semelhantes nos quatro municípios nos quais foram realizadas as pesquisas. O quadro abaixo apresenta o primeiro questionamento realizado aos sujeitos que consiste em buscar o entendimento do que é pobreza para os entrevistados.

Quadro 1 - Análise do Discurso do Sujeito coletivo frente ao questionamento do que é pobreza

\section{Expressões Chaves}

\section{O que é Pobreza para você?}

Sujeito 25 (S Bento do Sul): "pobreza é não ter nada e não ver saída desta situação, é tão difícil de dizer que nem consigo colocar tudo que penso, imagine é tudo de ruim que você possa imaginar [...]"

Sujeito 7 (Mafra): “pobreza é ver meus filhos sentindo a mesma dificuldade que eu senti quando era criança, é ter que repetir para eles o que eu ouvia da minha mãe ("isso não é coisa para pessoas pobres") hoje repito para minhas filhas, para mim pobreza é a falta de tudo, é a necessidade de ter que depender das outras pessoas (dinheiro, roupa, comida)"

Sujeito 11 (Irineópolis): "é a falta de dinheiro, sem dinheiro falta todo o resto, não se tem comida, roupa nova, coias para oferecer para seus filhos, acho que tudo se resume em falta de tudo... até de esperança [...] o meu mundo é muito diferente o seu"

Sujeito 3 (Três Barras): “pobreza é ser visto de forma diferente pelas pessoas, sentir vergonha por não conseguir ser melhor do que o dia de ontem e saber que os próximos amanhãs serão todos iguais, sem dinheiro, tem trabalho, sem vida digna me sinto preso a esta condição ".

\section{Ideia Central}

Pobreza é a falta de tudo, dinheiro, esperança, é ter que depender de outras pessoas é sentir vergonha de ser visto diferente pela sociedade.

\section{Discurso Síntese:}

A pobreza é não se ter dinheiro, não conseguir oferecer melhores coisas para seus filhos, é depender da ajuda de outras pessoas sempre. É sentir que se é tratado de forma diferente pela sociedade, muitas vezes deixado de lado, quando as oportunidades vão ficando cada vez mais difíceis de serem encontradas, isso só faz com que sejamos mais pobres. Até parece que ser pobre é bom, e que não queremos melhorar, as pessoas com mais dinheiro devem pensar que não queremos crescer como elas, até queremos mais não temos a mesma oportunidades, o nosso mundo é diferente não se tem a mesma liberdade de quem tem dinheiro.

Fonte: Dados do estudo (2014)

DRd - Desenvolvimento Regional em debate (ISSNe 2237-9029) 
É possível observar nos depoimentos do quadro acima que a pobreza também é compreendida pelo sujeito entrevistado a partir de uma leitura multidimensional, pela qual a falta de dinheiro, e os recursos adquiridos com ele, muitas vezes, é apresentada como primeira condição de pobreza. Porém verifica-se um reconhecimento da falta de oportunidade, da indiferença social e liberdade.

Desta forma pode-se identificar no discurso deste grupo a ausência de liberdade de escolha, fator que os mantém na condição de pobreza, pois estes podem até escolher não serem sujeitos pobres ou não estarem em condição de pobreza, principalmente devida às condições que estão expostas os priva da liberdade de simplesmente mudar de vida, ao buscarem oportunidades (fator presente no discurso individual de muitos participantes), faltalhes espaço e aceitação na sociedade.

Santos (2007) descreve que a pobreza quando definida como privação de capacidades acaba por refletir na liberdade das pessoas e Sen (2001) classifica três razões distintas para liberdade; (1) a que por si só gera bem estar, (2) a que permite a realização de funcionamentos relevantes para o bem estar e (3) a que possibilita ao individuo a realizar a condição de agente social. Desta forma a privação de liberdade pode contribuir para o empobrecimento dos sujeitos.

Outro questionamento levantado por este estudo buscou por um entendimento referente ao porque existem pessoas em situação de pobreza. Abaixo é possível identificar os relatos apresentados.

Quadro 2 - Análise do Discurso do Sujeito Coletivo frente ao questionamento do porquê existem pessoas em condição de pobreza.

Expressões Chaves

Por que existem pessoas em condição de pobreza?

Sujeito 12 (S Bento do Sul): "falta de oportunidades desde criança, não estudei, fui morar com uma pessoa muito nova, para sair de casa, hoje tenho 5 filhos destes 2 pequenos, estou sozinha, não consigo trabalhar. Mais resumo tudo em falta de estudo e isso leva a falta de oportunidade, sem estudo não tem trabalho. Pense, tenho 39 anos estudei até a $5^{\text {a }}$ série e tenho 5 filhos, você acha que alguém vai me dar trabalho?"

Sujeito 21 (Mafra): "não tem emprego, já andei a cidade toda atrás de um mais ninguém precisa, na verdade eu sei e sinto que ninguém quer contratar pessoas mais velhas com pouco estudo, não sei falar bonito, não tenho roupas boas, isso conta muito. Hoje eu trabalho por dia, mais sabe como é né, hoje tem e manhã não tem. Mas é como vou levando a vida e dando de comer e vestir para meus filhos. Hoje sinto a importância do estudo".

Sujeito 2 (Irineópolis): "não sei dizer com certeza, mas eu estou assim porque não estudei. Só consigo trabalho por dia, quando alguém dá, do tipo, limpar uma casa ou outra, mais não fico muito tempo, logo as pessoas não querem mais. Sou pobre porque não consigo ver formas de deixar de ser pobre”

Sujeito 18 (Três Barras): "falta de trabalho, não estudei. Hoje o estudo conta muito, sem ele não se consegue fazer serviço nenhum. Não terminei a oitava série, sei ler e sei escrever mais é pouco e já tenho 40 anos. Hoje esta cheio de gente mais nova, com muito mais estudo. Tenho feito alguns cursinhos profissionalizantes para ver se ajuda, mais a professora já falou, se eu não voltar estudar não vou conseguir"

\section{Ideia Central}

A falta de estudo leva a falta de oportunidade de trabalho, fator que impede a superação da condição de pobreza. Discurso Síntese:

Existem pessoas em condição de pobreza porque não estudaram, a falta do estudo atrapalha para conseguir trabalho, sem trabalho não tem dinheiro, a falta de estudo provoca a falta de condições de trabalho digno, sem trabalho digno não tem experiência sem experiência e com idade avançada aí situação fica pior.

Fonte: Dados do estudo (2014)

DRd - Desenvolvimento Regional em debate (ISSNe 2237-9029) 
O discurso apresentado acima aponta o direcionamento para a falta de estudo como principal provocador da falta de oportunidade, logo, estar em condição de pobreza. Este direcionamento no discurso pode ser relacionado com dados já identificados nas características demográficas apresentadas anteriormente, as quais mostram percentual de 91,29\% dos entrevistados que possuem escolaridade de até o $1^{\circ}$ grau concluído.

Pontili (2004) descreve que muitas pesquisas foram realizadas na área da economia e os resultados têm apontado a importância da escolaridade como fator desencadeador de uma melhoria da qualidade de vida dos sujeitos. Deve-se considerar então que a educação ao compor um dos direitos fundamentais do sujeito, visa o seu preparo para o exercício da cidadania e a qualificação para o trabalho.

Ao se perceber no discurso dos sujeitos participantes do estudo que a falta de escolaridade é um fator provocador da falta de oportunidades, principalmente de trabalho na vida destes sujeitos, é possível identificar pelos discursos o sentimento dos participantes frente à responsabilidade que possuem por sua condição de pobreza, onde $11,30 \%(\mathrm{~N}-13)$ referem não se sentirem responsáveis por sua condição atual e repassam a responsabilidade ao estado que não oferece melhores condições de vida e principalmente de mais trabalho. E $88,70 \%(\mathrm{~N}-102)$ referem sentirem-se responsáveis pela sua condição; este resultado pode justificar-se ao ser relacionado com o quadro 2 que questiona o porquê da existência da pobreza e o discurso coletivo identificado pauta-se na falta de escolaridade. A tabela abaixo apresenta o discurso individual de sujeitos que complementam sua justificativa para esta relação

Quadro 3 - Discurso individual de sujeitos sobre a responsabilidade pela sua condição de pobreza.

SIC "sou pobre porque não estudei, nunca gostei da escola desde pequeno e meus pais não me mandavam ir, isso fez com que eu desistisse muito cedo (estudei até a $5^{\mathrm{a}}$ série), pois achava que ir para a escola era perca de tempo, naquela época eu gostava mesmo de brincar, depois o tempo foi passando, passei a trabalhar nas casas para ter um dinheirinho, e quando comecei buscar serviço de verdade, vi que devia ter estudado mais, e que ia ser difícil ter um trabalho bom" (Sujeito 22 município de Mafra)

SIC "sou muito responsável sim, tanto que hoje obrigo meus filhos irem para escola, pois sei qual vai ser o futuro deles se não estudarem [...]" (Sujeito 28 Três Barras)

SIC “ quando vi que devia ter estudado mais para conseguir trabalho, voltei a estudar, estas escolas especiais, mais não consegui acompanhar. Hoje não consigo trabalhar registrada, pois não tenho a oitava série e não adianta, não consigo aprender as coias, já estou muito velha”. (Sujeito 11 São Bento do Sul)

SIC "sem estudo não tem trabalho, sem trabalho não tem dinheiro, sem dinheiro sou pobre" (Sujeito 3 Irineópolis)

Fonte: Dados do estudo (2014)

Outro dado importante manifestado pelos entrevistados para a composição deste estudo tratou da possibilidade de saírem da situação de pobreza que se encontram. A tabela abaixo mostra a distribuição numérica deste entendimento relacionando os sujeitos aos municípios que pertencem. 
Tabela 2 - Entendimento sobre a possibilidade de sair da condição de pobreza que se encontram.

\begin{tabular}{l|c|c|c|c}
\hline \multirow{2}{*}{ Municípios } & \multicolumn{2}{c|}{ SIM } & \multicolumn{2}{c}{ NÃO } \\
\cline { 2 - 5 } & Freq & $(\%)$ & Freq & $(\%)$ \\
\hline São Bento do Sul & 28 & 90,32 & 3 & 9,68 \\
\hline Mafra & 34 & 94,44 & 2 & 5,56 \\
\hline Irineópolis & 18 & 100 & 0 & 0 \\
\hline Três Barras & 24 & 80 & 6 & 20 \\
\hline Total & 104 & 90,43 & 11 & 9,56 \\
\hline
\end{tabular}

Fonte: Dados do estudo (2014)

O quadro acima demonstra que 90,43\% (N104) dos sujeitos entendem que existe a possibilidade de saírem da situação de pobreza atual e 9,57\% (N11) entendem que não existe possibilidade de sair desta condição. A tabela 06 apresenta o discurso individual de sujeitos ao complementarem o questionamento da entrevista.

Quadro 4 - Entendimento sobre a possibilidade de saírem da condição de pobreza que se encontram

SIC "existe possibilidade sim, mais depende muita coisa, voltei a estudar, também estou participando de alguns cursos profissionalizantes oferecidos pela prefeitura, queria ter certeza que é só isso, para que eu possa trabalhar registrada e daí possa ser feliz, sem me preocupar se amanhã vou ter dinheiro para comprar comida ou roupa para meus filhos, vou andar na rua de cabeça erguida, me sentindo igual a todo mundo" (Sujeito 12 município de Mafra)

SIC “já estou fazendo meus filhos irem para escola, não deixo perder um dia, se meus pais tivessem feito isso comigo talvez eu estivesse melhor de vida, mais agora não da para olhar para traz, tenho que olhar para frente e não deixar que meus filhos tenho a mesma vida que eu" (Sujeito 8 Três Barras)

SIC “estou certa que da para melhorar, até porque já melhorei muito, eu já fui muito pobre, sem ter luz e água em casa, roubava água de noite nos vizinhos para poder tomar durante o dia, hoje eu estou estudando, faço uma matéria por vez porque não tenho mais cabeça para acompanhar, mais logo termino, daí vou buscar emprego igual a todo mundo". (Sujeito 19 São Bento do Sul)

SIC “eu não vejo forma de deixar de ser pobre, nunca fui diferente, meus pais tinham menos do que eu, acho que enquanto a sociedade não olhar melhor para nós vamos ser sempre os necessitados, eu não tenho esperança de ver as coisas mudar, acho que morro antes" (Sujeito 11 Irineópolis)

Fonte: Dados do estudo (2014)

É possível observar nos discursos individuais apresentados acima que algumas estratégias já estão sendo utilizadas na tentativa de mudar de situação. Os entrevistados buscam a liberdade de escolherem em que condições querem viver. Isso pode ser identificado nos discursos dos sujeitos do município de Mafra, Três Barras e São Bento do Sul, quando apontam alternativas como voltar a estudar, participar de cursos profissionalizantes oferecidos pelos Programas de Fortalecimentos de Vínculos, manter os filhos na escola.

Ainda pautada na teoria apresentada por Amartya Sen é possível analisar nos discursos acima a necessidade dos sujeitos entrevistados para este estudo pela busca, atendimento de liberdade para usufruírem e realizarem aquilo que pode agregar valor, neste caso, o trabalho, o reconhecimento social. Esta afirmativa converge com a abordagem seniana, na qual a liberdade é considerada intrinsecamente importante por enriquecer a vida humana, a partir do favorecimento de oportunidades da pessoa ter resultados e participação social (FREIRE, 2011).

DRd - Desenvolvimento Regional em debate (ISSNe 2237-9029) 
Santos (2007) complementa a ideia descrevendo que a expansão da liberdade deve ser vista como principal fim ${ }^{11}$ e principal meio ${ }^{12}$ do desenvolvimento.

A entrevista utilizada como instrumento de coleta de dados também indagou aos sujeitos sobre o que poderia contribuir para que saíssem desta situação. O quadro abaixo apresenta estes dados.

Quadro 5 - Análise do Discurso do Sujeito Coletivo sobre o questionamento do que poderia contribuir para os entrevistados sairem da condição de pobreza.

Expressões Chaves

O que poderia contribuir para você sair desta situação?

Sujeito 23 (S Bento do Sul): “mais emprego"

Sujeito 21 (Mafra): "mais oportunidade de trabalho digno, não é por que sou pobre que não posso ter um trabalho bom, em um lugar limpo, parece que as pessoas esperam que os pobres façam o trabalho ruim e o rico o trabalho bom, agora estou trabalhando em lugar ruim porque ainda estou estudando, ainda sou pobre, mais quero ir trabalhar em um lugar bom ".

Sujeito 2 (Irineópolis): "duas coisas, mais trabalho e melhorar a renda do benefício, pois é muito baixa e não da para fazer muita coisa, tenho 5 filhos dar de comer e vestir todo mundo, não é barato"

Sujeito 18 (Três Barras): "mais oportunidade para trabalhar, na medida que as pessoas vejam que com o trabalho da para deixar de ser pobre e começarem a trabalhar e não ficar dependendo só de ajuda as coisas melhoram. Vejo muito gente que mora perto da minha casa que fica esperando a ajuda cair do céu, veja, tenho 4 filhas, meu marido foi embora... o que eu posso fazer, buscar trabalho para dar coisas para elas e ensinar elas serem diferentes ou ficar em casa esperando ajuda igual a muita gente e ensinar minhas filhas fazer a mesma coisa amanhã."

Discurso Síntese:

Ideia Central: Mais oportunidade de trabalho digno

Com mais oportunidade de trabalho, ficaria mais fácil sair desta condição.

Fonte: Dados do estudo (2014)

$\mathrm{Na}$ análise dos dados acima se direciona o estudo para relação trabalho e renda como alternativa de superação da condição de pobreza atual. Esta relação pode acontecer devido ao sentimento de privação, quando a falta de dinheiro leva à falta de condições, como o dinheiro tem uma relação direta com o trabalho, entende-se que se tiver trabalho se tem dinheiro, logo mais condições e menos privação.

Em geral, percebe-se uma dependência familiar relativamente grande das rendas dos chefes de família. Nesse estudo, quando se relaciona ao questionamento de quantas pessoas da

\footnotetext{
${ }^{11} \mathrm{O}$ papel constitutivo está associado às liberdades substantivas que inclui a capacidade de evitar a fome, a subnutrição, doenças que podem ser prevenidas, morte prematura, bem como as liberdades associadas à instrução, à participação política, à liberdade de expressão, etc. As liberdades substantivas devem ser consideradas importantes independentemente do interesse individual em exercê-las ou não: mesmo que uma pessoa não tenha vontade de exercer sua liberdade de expressão, por exemplo, seria uma privação se ela não pudesse ter a escolha por manifestar-se ou não. Essas liberdades são parte integrante do enriquecimento da vida humana (SANTOS, 2007, p.38).

12 Já as liberdades instrumentais são importantes na medida em que contribuem para promoção de outros tipos de liberdades (liberdade política, facilidades econômicas, oportunidades sociais, garantia de transparência e segurança protetora), que se inter-relacionam entre si, permitindo uma liberdade global do sujeito (SANTOS, 2007).
}

DRd - Desenvolvimento Regional em debate (ISSNe 2237-9029)

v. 6, n. 3, p. 235-260, nov. 2016. 
família estavam trabalhando (formal ou informalmente), identificou-se que dos grupos familiares que estavam inseridos no mercado de trabalho $23,47 \%$ (N27), e apenas um membro familiar trabalhando informalmente, o restante dos sujeitos participantes do estudo 76,52\% (N88) encontram-se fora do mercado de trabalho.

Considerando que todos os integrantes do estudo, inseridos ou não no mercado de trabalho, eram beneficiários do Programa Bolsa Família, a questão sobre a posição dos sujeitos, frente ao conhecimento que os entrevistados possuem sobre os programas para o enfrentamento da pobreza oferecidos por seu município, pode-se observar que $80,87 \%$ (N93) disseram conhecer a existência de programas de enfrentamento à pobreza oferecidos em seu município e 19,13\% (N22) assumiram não conhecer programas oferecidos com esta finalidade, mesmo estando inseridos e estarem sendo beneficiados pelo PBF.

Este estudo possuiu também como objetivo a identificação dos programas oferecidos pelos municípios onde aconteceu a pesquisa, com o propósito de enfrentamento à pobreza. A tabela abaixo apresenta os programas oferecidos e o número de beneficiários.

Tabela 3 - Programas de enfrentamento a pobreza oferecidos nos municípios onde ocorreu o estudo.

\begin{tabular}{lcccc}
\hline & São Bento do Sul & Mafra & Três Barras & Irineópolis \\
\hline Programa Bolsa Família & 1126 & 1643 & 1047 & 685 \\
BPC - Idosos & 251 & 157 & 30 & 137 \\
BPC - PCD & 335 & 398 & 88 & 03 \\
Renda Mensal Vitalícia & 18 & 09 & 01 & 00 \\
& & BENEFICICÁRIOS & \\
\hline
\end{tabular}

Fonte: Ministério do Desenvolvimento Social (maio/2014)

Quando comparados com dados anteriores sobre o conhecimento dos participantes do estudo frente aos programas oferecidos, observa-se que o Benefício de Prestação Continuada (BPC) - Idosos, o Benefício de Prestação Continuada (BPC) Pessoa com deficiência e a Renda Mensal Vitalícia não foram apontados pelos sujeitos. Isso pode ser relacionado ao fato de que os entrevistados consideram como programas existentes somente os programas que tem acesso.

A entrevista encerrou-se com um questionamento aos sujeitos referente à sua percepção sobre a melhoria de sua condição de vida após a inclusão em um programa social.

Identificou-se que 100\% (N115) manifestaram ter melhorado a sua condição de vida a partir da entrada em programas sociais, que para eles resumiu-se ao PBF. O quadro abaixo apresenta a manifestação de discurso do sujeito coletivo construído a partir da especificação das melhorias vivenciadas pelos sujeitos do estudo. 
Quadro 6 - Análise do Discurso do Sujeito Coletivo frente ao questionamento sobre a especificação das melhorias vivenciadas a partir da inclusão no PBF.

Qual melhoria foi percebida em sua condição de vida após a sua inclusão no PBF?

Expressões Chaves

Sujeito 16 (S Bento do Sul): “pude comprar mais coisas, não são muitas, mas já da para oferecer o mínimo para meus filhos, de vez em quando trabalho de faxineira e já entra um pouco mais de dinheiro (R\$ 50,00 dia), com isso atendo as necessidades da minha família"

Sujeito 29 (Mafra): “consegui melhorar algumas coisas em minha casa, comprei TV, uma cozinha nova, fico muito feliz quando estou em casa e vejo que as coisas estão melhorando, bem de vagar, mais a 5 anos atrás eu morava de favor no quartinho de uma amiga, tinha uma pia e dois colchões, hoje tenho até TV, sou muito feliz".

Sujeito 2 (Irineópolis): “consigo comprar as coisas, pouquinhas, mais não falta mais comida, o restante as outras pessoas ajudam, com roupas que não usam mais, ou moveis que iam jogar fora, é assim que eu vou conseguir as coisas. $O$ bolsa família me ajuda com a comida necessária para a sobrevivência, tomara que eu nunca perca."

Sujeito 18 (Três Barras): “como melhorei, não preciso mais dizer não para tudo para meus filhos, me sinto mais importante quando vou no mercado e consigo comprar e pagar minhas compras, sinto que não devo nada para ninguém, me sinto mais digna.".

Ideia Central: Aquisição de bens materiais, dignidade e autonomia.

Discurso Síntese:

O PBF ajuda muito, consegui comprar coisas para a casa, oferecer necessidades mínimas para meus filhos, me sinto mais importante e capaz de me manter sozinha, sem ficar pedindo tudo.

Fonte: Dados do estudo (2014)

Pelo discurso acima é possível identificar a percepção de melhoria na condição de vida após ter acessado o benefício do Programa Bolsa Família, e que esta melhoria refere-se à aquisição de bens materiais, ficando claro no discurso acima que a principal melhoria incide na autonomia e no sentimento de dignidade.

A analisar o discurso acima, pode-se identificar que a inclusão destas famílias no PBF ameniza a ausência de dois dos tipos de liberdades propostos por Sen (2000).mIsso é identificado quando em discursos individuais destacam-se essencialmente a aquisição de alimentos, roupas e bens materiais.

Porém, um segundo tipo de liberdade revela-se amenizada para estes sujeitos após o acesso ao Programa. Trata-se da liberdade política e civil, que se caracteriza pela restrição da participação das pessoas em determinados grupos sociais ou econômicos. Identifica-se que as pessoas beneficiadas podem passar participar mais ativamente na sociedade em que vivem, quando em discursos individuais entrevistados se manifestam dizendo que "hoje não tenho vergonha de andar na rua, sempre te recebo aproveito para comprar as coisas que estão faltando, e faço isso me sentindo importante, igual as outras pessoas" (SIC).

A partir do discurso dos sujeitos pesquisados para este estudo, quando perguntados sobre o que é pobreza, do porque existem pessoas nesta condição, quais fatores contribuíram para que a condição destas pessoas fosse esta, de que forma o Estado contribui para a superação desta condição e, que melhorias foram identificadas nas suas vidas a partir do momento em que foram incluídos em programas sociais de erradicação à pobreza, buscou-se

DRd - Desenvolvimento Regional em debate (ISSNe 2237-9029) 
o entendimento de uma possível relação entre a pobreza dos sujeitos pesquisados para o estudo e as condições da região que vivem.

A partir desta definição realizou-se uma pesquisa buscando caracterizar a pobreza na região estudada, considerando que o Planalto Norte Catarinense é tido nas mensurações estaduais como um território de concentração de pobreza. A Tabela abaixo apresenta os números encontrados relacionado com os quatro municípios estudados.

Tabela 4 - Representação da pobreza nos municípios estudados.

\begin{tabular}{l|c|c|c|c}
\hline & $\begin{array}{c}\text { São Bento do } \\
\text { Sul }\end{array}$ & Mafra & Três Barras & Irineópolis \\
\hline IDHM & 0,76 & 0,73 & 0,70 & 0,69 \\
\hline $\begin{array}{l}\text { População Municipal - } \\
\text { habitantes }\end{array}$ & 74.801 & 52.912 & 18.129 & 10.448 \\
\hline Cad Único & 4.293 & 6.991 & 3.177 & 1.377 \\
\hline Pobreza Extrema & 527 & 1.021 & 647 & 479 \\
\hline Programa Bolsa Família & 1.126 & 1.643 & 1.047 & 685 \\
\hline $\begin{array}{l}\text { Beneficio Social de Pobreza } \\
\text { Extrema (BSPE) }\end{array}$ & 169 & 306 & 649 & 42 \\
\hline BPC - Idosos & 251 & 157 & 30 & 25 \\
\hline BPB - Pessoas com Deficiência & 335 & 398 & 88 & 137 \\
\hline
\end{tabular}

Fonte: MDS (maio 2014)

Ao se observar o quadro acima se constata que o município de São Bento do Sul possui $1,5 \%$ da sua população como beneficiária do PBF, o município de Mafra possui 3,10\% da sua população na condição de beneficiária do PBF, o município de Três Barras possui $5,77 \%$ de sua população na condição de beneficiária do PBF e o município de Irineópolis possui 6,55\% de sua população na condição de beneficiários do Programa Bolsa Família.

Estes dados permitem a relação do estudo com afirmativa de Amartya Sen (2000) quando este escreve que a visão do que é ser pobre é influenciada pela determinação do espaço em que esta pobreza é apreciada. É possível verificar pelo quadro que os municípios de Irineópolis e Três Barras possuem o menor IDHM do grupo estudado e consequentemente apresentam um maior percentual de pessoas beneficiárias pelo Programa Bolsa Família.

Este fator nos remete ao pensamento de que quanto menor foi o IDHM maior é a confirmação da existência da pobreza e da exclusão. Pois, para se analisar o nível de desenvolvimento é preciso considerar a relação de altos índices de pobreza às condições e às possibilidades de melhoria da sociedade.

\section{DESAFIOS DA POBREZA PARA O DESENVOLVIMENTO NO PLANALTO NORTE CATARINENSE}

Superar o cenário de região não desenvolvida é o desafio ao Planalto Norte Catarinense, que comprovadamente é uma região de condições vulnerabilizadoras tanto é que se tornou objeto da implementação do Programa governamental Territórios da Cidadania. 
Os municípios do Planalto Norte Catarinense muito pouco se diferem entre si em termos sócio produtivos, mesmo com que tenha certo diferencial de desenvolvimento nos extremos dessa região. Porto União e Rio e Negrinho e São Bento do Sul formam dois nichos com certo desenvolvimento, nos quais a produção e a indústria se destacaram e se tornaram atrativos aos trabalhadores da região, fazendo com que o êxodo rural-urbano-urbano acontecesse produzindo consequências, entre elas o formação de bolsões de pobreza.

Ainda no que tange aos desafios, essa região preserva projetos societários sustentados em uma herança de diversidades (multirracial, cultural, política, ética e ambiental), como síntese das ações e pensamentos dos migrantes atraídos pelo atrativo da potencial economia eficaz regional.

Frente a essas reflexões constata-se que a pobreza nas sociedades capitalistas é uma questão central, não importa o potencial atrativo econômico que se apresente. Portanto, o enfrentamento da pobreza como uma direção social e política brasileira no pós constituição de 1988, foi um dos recursos estratégicos para o desenvolvimento. Isto é, em realidades com essas condições o desafio perpassa pelo delineamento de intervenções que deveriam promover desfechos ao desenvolvimento nas dimensões sociais, econômicas, educacionais, culturais e também políticas. Trata-se de acionar transformações societárias em que os atores possam reconhecer-se, conjugarem-se, corresponsabilizarem-se e coparticiparem do redirecionamento ético-político da classe trabalhadora.

\section{CONSIDERAÇÕES FINAIS}

Concluídas as etapas para o desenvolvimento deste estudo apresentam-se as considerações finais, buscando responder as questões que nortearam a problemática central proposta, de identificar quais são as representações sociais dos sujeitos que vivem em condição de pobreza e sua interferência no desenvolvimento do Planalto Norte Catarinense.

Um questionamento que norteou este estudo foi o de identificar quais políticas públicas direcionadas ao enfrentamento à pobreza são aplicadas neste recorte territorial. Identificou-se que as políticas aplicadas a este recorte são Programa Bolsa Família (PBF) atendendo 9.968 famílias, o Benefício Social de Pobreza Extrema (BSPE), atendendo 1.596 famílias, a Renda Mínima Vitalícia (RMV) atendendo 28 pessoas, o Beneficio de Prestação Continuada - Idosos e Pessoas com Deficiência, atendendo 1.399 pessoas. Das participantes do estudo 100\% são beneficiárias do Programa Bolsa Família.

Como terceira questão que norteou este estudo identificou-se o entendimento que o sujeito pobre possui sobre a sua condição. A partir da técnica de análise do discurso do sujeito coletivo verificou-se que o sujeito pobre compreende a pobreza a partir de uma visão multidimensional, onde a falta de dinheiro, a falta de oportunidade, a falta de liberdade e a indiferença social se fazem presentes em seus discursos.

A pesquisa revelou que os sujeitos pobres entendem que existem pessoas nesta condição principalmente devido à falta de estudos, que leva a falta de oportunidade de trabalho digno. 
Quanto à percepção de sua responsabilidade sobre a condição atual que vivem, verificou-se que $88,70 \%$ dos participantes sentem-se responsáveis e apontam a falta de estudo e a falta de oportunidade como principais fatores provocadores desta realidade. No entanto, a leitura da possibilidade de sair desta situação se faz presente no discurso de $90,43 \%$ dos sujeitos e também no comportamento de muitos deles quando afirmam que retomaram seus estudos e que participam de cursos profissionalizantes oferecidos pelo Programa de Fortalecimento de Vínculos de seu município.

A oportunidade de trabalho digno esteve presente no discurso dos sujeitos quando apontados os fatores que poderiam contribuir para que os mesmos saíssem da situação em que se encontram.

Quanto aos Programas de enfrentamento à pobreza oferecidos pelos municípios pertencentes ao território estudado, verificou-se no discurso de $80,87 \%$ dos participantes, o conhecimento sobre o Programa Bolsa Família, porém os demais já citados anteriormente (BPC - Idosos/ BPC Pessoas com Deficiência e RMV) não se fizeram presentes durante o discurso. Logo se pode concluir que 19,13\% dos participantes do estudo são beneficiários do Programa Bolsa Família, porém este apontamento não faz parte do discurso dos mesmos como um programa de enfrentamento à pobreza.

Este estudo tratou da pobreza a partir da visão de privação de capacidades básicas, quando a renda baixa é um fator reconhecido como uma das principais causas da pobreza, porém não a única. Acredita-se que a pobreza deve ser vista a partir de um entendimento de privação de liberdade, pois uma renda mais alta permite maiores condições de liberdade de escolha.

Agora, quando pensamos na forma de como as representações sociais, ou seja, o entendimento que os sujeitos possuem sobre o sentimento de ser pobre se relaciona com o desenvolvimento da região do Planalto Norte Catarinense, podemos apontar que os sujeitos conseguem fazer uma relação de seu desenvolvimento pessoal com o desenvolvimento de seu município. Isso mostra-se evidente durante a analise das entrevistas, quando se identifica em fragmentos dos discursos dos sujeitos participantes uma relação direta da ausência de oportunidades com a realidade que observam no espaço que vivem, apontando que existem muitas pessoas na mesma condição que eles, ou até mesmo pior, pois quando não estavam inseridos em nenhum programa de beneficio social a pobreza se fazia bem mais evidente. Estes entrevistados assumem poder ajudar as outras pessoas em condição mais comprometida que a sua, pois hoje já estão menos pobres.

O sentimento de não ser mais pobre, ou estar em uma condição de pobreza menor atualmente, justifica-se quando se analisa a questão de que todos as participantes do estudo são beneficiárias do PBF logo, pode-se dizer que o fato de elas terem sido beneficiadas com um programa e estarem participando de uma circulação comunitária e social as faz entenderem-se como alguém que já venceu alguns obstáculos, sentirem-se mais livres para fazer escolhas no contexto social. A compreensão de pobreza e a autodefinição de pobreza nesta situação acaba por ser superada pelo fato de que agora possuem um pouco mais de condição de atender suas necessidades mínimas.

Verificou-se em fragmentos do discurso dos sujeitos participantes do estudo que a sua condição acaba indiretamente refletindo no crescimento de sua cidade (principalmente a partir

DRd - Desenvolvimento Regional em debate (ISSNe 2237-9029) 
de uma leitura de renda versus poder de compra) e também a partir da percepção de condição de estudo, versus oportunidade de trabalho.

Desta forma conclui-se então que os elementos identificados neste estudo reforçam a visão de que o desenvolvimento da região também está relacionado com a sensação de liberdade de escolhas e de envolvimento social de seus sujeitos, permitindo que os mesmos possam fazer e sentirem-se ativos no processo de crescimento pessoal e crescimento de seu território, pois a ausência de entendimento sobre o seu crescimento pessoal impede a leitura de crescimento de território.

Por fim, tomando-se por base as teorias do desenvolvimento e do desenvolvimento regional, uma reflexão é possível, no que diz respeito à região do Planalto Norte Catarinense sobre a qual se desenvolveu o estudo. Com o aporte em Dallabrida (2004), reitera-se que no escopo do desenvolvimento e, por conseguinte, do desenvolvimento regional, este deve compor a agenda política de uma sociedade, na qual deve prioritariamente ser discutido e refletido o desenvolvimento pelos âmbitos sociais, políticos, culturais e ambientais de uma determinada sociedade.

Sob o foco da reflexão de Cabugueira (2000), uma região é uma entidade real, objetiva e concreta de fácil identificação, então a pobreza existente no Planalto Norte Catarinense, impõe autoconhecimento não apenas dos entes institucionais, mas das populações que devem reconhecerem-se como sujeitos atuantes sobre os processos dos quais fazem parte e pelos quais suas condições objetivas e subjetivas de vida lhes sejam favorecidas. Nessa perspectiva as transformações societárias advém da implementação de intervenções, que além de motivação dos sujeitos, lhes represente seus dilemas, seus desafios, suas perspectivas. A reversão dos indicadores de pobreza no desenvolvimento das regiões devem se compor do desafio prioritário, com sentido ético e político, alterando a determinação econômica que dominou as politicas públicas de desenvolvimento. $\mathrm{O}$ desenvolvimento e, por conseguinte, o desenvolvimento regional só será desenvolvimento se ocorrer a presença ativa e participativa de todos os atores e deles fazendo parte, os que são incluídos no grupo de beneficiários da transferência de renda.

\section{REFERÊNCIAS}

ALVES-MAZZOTTI, A. J. Representações sociais: aspectos teóricos relacionados a educação. Múltiplas leituras, Rio de Janeiro, v. 1, n. 1, p.29-45, 01 jul. 2008. Disponível em: <https://www.metodista.br/revistas/revistas-ims/index.php/ML/article/viewFile/1169/1181>. Acesso em: 20 out. 2013.

ARRUDA, A. Teoria das Representações Sociais de Gênero. Cadernos de Pesquisa, Rio de Janeiro, v. 1, n. 117, p.127-148, 01 nov. 2002. Disponível em: <http://www.scielo.br/pdf/cp/n117/15555.pdf>. Acesso em: 16 out. 2013.

BOISIER, S. Sociedad civil, actores sociales y desarrollo regional. Santiago de Chile: ILPES/DPPR, 1996 (Serie Investigación, Doc. 95/14). 
CABUGUEIRA, A. C. C. M. Do desenvolvimento regional ao desenvolvimento local: Análise de Alguns Aspectos de Política Econômica Regional. Gestão e Desenvolvimento, n. 9, p. $103-136,2000$.

CRESPO, A P A; GUROVITZ, E. A pobreza como um fenômeno multidimensional. Rae Eletronica, São Paulo, v. 1, n. 2, p.1-12, 30 jul. 2002. Mensal. Disponível em: <http://www.scielo.br/pdf/raeel/v1n2/v1n2a03.pdf>. Acesso em: 07 jul. 2013.

DALLABRIDA, V. R. Planejamento territorial: algumas observações teóricas e análise da prática. Santa Cruz do Sul: EDUNISC, 2004.

DINIZ, C. C. Repensando a questão regional Brasileira: tendências, desafios e caminhos. Painel sobre o desenvolvimento brasileiro. Rio de Janeiro: BNDS, 2002.

IBGE (Instituto Brasileiro de Geografia e Estatística). Censo 2010. Disponível em: <http://www.ibge.gov.br/home/estatistica/populacao/censo2010/calendario.shtm>. Acesso em: 16 out. 2013.

IPEA (Instituto de Pesquisa Econômica e Aplicada). Erradicação da Pobreza no Brasil. Disponível em: <www.ipea.gov.br〉. Acesso em: 10 jul. 2013.

LEFÈVRE, F.; LEFÈVRE, A. M. C; TEIXEIRA, J. J. V. O discurso do sujeito coletivo: uma nova abordagem metodológica em pesquisa qualitativa. Caxias do Sul: EDUCS, 2000.

MOSCOVICCI, S. Representações sociais: investigações em psicologia social. 2. ed. Petropolis: Vozes, 2003.

PAUGAM, S. A desqualificação social: ensaio sobre a nova pobreza. trad. Camila Giorgetti, Teresa Lourenço. São Paulo: Educ/Cortês, 2003.

PEREIRA-PEREIRA, P A. Necessidades humanas: subsídios à crítica dos mínimos sociais. São Paulo: Cortez Editora, 2000.

PNUD (Programa das Nações Unidas Para o Desenvolvimento). Desenvolvimento humano e IDH. Disponível em: <http://www.pnud.org.br/IDH/DH.aspx>. Acesso em: 12 maio 2013

PONTILI, R. A infraestrutura escolar e as características familiares influenciando a frequência e o atraso no ensino fundamental. Piracicaba: ESALQ/USP, 2004.

ROCHA, S. Pobreza no Brasil: afinal do que se trata. Rio de Janeiro: FGV, 2006.

SANTOS, L. M. N. Pobreza como privação de liberdade: um estudo de caso na favela do Vidigal no Rio de Janeiro. Niterói, 2007. 191 p. Dissertação (Mestrado em Economia) - PósGraduação em Economia, Universidade Federal Fluminense, Niterói. 2007. Disponível em: http://www.bdtd.ndc.uff.br/tde_arquivos/40/TDE-2008-02-11T131509Z-1261/Publico/2007larissa_martins.pdf >. Acesso em: 21 maio 2014.

SEN, A K. Desenvolvimento como liberdade. São Paulo: Companhia das Letras, 2000. 
SILVA, A C; BANDEIRA, E S F; LOPES, E B. Anais: aspectos conceituais e o processo de construção histórica.. In: JORNADA INTERNACIONAL DE POLÍTICAS PÚBLICAS, 5. 2011, São Luiz, Maranhão. Pobreza no Brasil. São Luiz Maranhão: Ufma, 2011. v. 1, p. 1 9. Disponível em: <http://www.joinpp.ufma.br/index.php>. Acesso em: 10 ago. 2013.

SILVA, L M; BARROS, S M. Bolsa Família-Estratégia de Enfrentamento a Pobreza no Brasil. In: JORNADA INTERNACIONAL DE POLÍTICAS PðBLICAS, 3., 2007. Anais... São Luiz, Maranhão: Ufm, 2007. v. 1, p. 1 - 8. Disponível em:

<http://www.joinpp.ufma.br/jornadas>. Acesso em: 25 ago. 2013.

SILVA, L. P. V. Pobreza e suas formas de resistência e enfrentamento no Município de Belágua - MA. 2004. Dissertação (Mestrado em Políticas Públicas) - Programa de PósGraduação em Políticas Públicas. Universidade Federal do Maranhão, 2004.

SILVA, M. O. S. O debate sobre a pobreza: questões teórico-conceituais. Revista de Políticas Públicas, São Luís, v. 6, n. 2, p. 65-102, jan/jun, 2000.

VINHAS, H. E. F. Ensaio sobre a redução da pobreza no Brasil: mensuração e determinantes. 2006. 158 f. Dissertação (Mestrado em Economia) - Universidade de São Paulo, São Paulo, 2006. Disponível em: <www.teses.usp.br>. Acesso em: 10 jul. 2013.

Artigo recebido em: 31/10/2016

Artigo aprovado em: 14/11/2016 